University of Nebraska - Lincoln

DigitalCommons@University of Nebraska - Lincoln

Faculty Papers and Publications in Animal

Science

Animal Science Department

August 2005

\title{
Estimation of Genetic Parameters for Growth, Feed Consumption, and Conformation Traits for Double-Muscled Belgian Blue Bulls Performance-Tested in Belgium
}

\author{
N. Gengler \\ UER de Zootechnie, Faculte Universitaire des Sciences Agronomiques de Gembloux, Belgium \\ C. Seutin \\ UER de Zootechnie, Faculte Universitaire des Sciences Agronomiques de Gembloux, Belgium \\ F. Boonen \\ Centre de Selection de la Race Blanc-Bleue Belge, B-5590 Ciney, Belgium \\ L. Dale Van Vleck \\ University of Nebraska-Lincoln, dvan-vleck1@unl.edu
}

Follow this and additional works at: https://digitalcommons.unl.edu/animalscifacpub

Part of the Animal Sciences Commons

\footnotetext{
Gengler, N.; Seutin, C.; Boonen, F.; and Van Vleck, L. Dale, "Estimation of Genetic Parameters for Growth, Feed Consumption, and Conformation Traits for Double-Muscled Belgian Blue Bulls Performance-Tested in Belgium" (2005). Faculty Papers and Publications in Animal Science. 257.

https://digitalcommons.unl.edu/animalscifacpub/257

This Article is brought to you for free and open access by the Animal Science Department at DigitalCommons@University of Nebraska - Lincoln. It has been accepted for inclusion in Faculty Papers and Publications in Animal Science by an authorized administrator of DigitalCommons@University of Nebraska - Lincoln.
} 


\title{
Estimation of Genetic Parameters for Growth, Feed Consumption, and Conformation Traits for Double-Muscled Belgian Blue Bulls Performance-Tested in Belgium
}

\author{
N. Gengler*,1, C. Seutin*, F. Boonent, and L. D. Van Vleck \\ *UER de Zootechnie, Faculté Universitaire des Sciences Agronomiques de Gembloux, \\ B-5030 Gembloux, Belgium; 'Centre de Sélection de la Race Blanc-Bleue Belge, B-5590 Ciney, \\ Belgium; and ₹Roman L. Hruska U.S. Meat Animal Research Center, ARS, USDA, \\ University of Nebraska, Lincoln 68583
}

\begin{abstract}
For 1,442 Belgian Blue bulls performance-tested at the Centre de Sélection de la Race Blanc-Bleue Belge, nine traits were observed: height at withers at $7 \mathrm{mo}$, height at withers at $13 \mathrm{mo}$, weight at $7 \mathrm{mo}$, weight at $13 \mathrm{mo}$, average feed consumption of concentrates, average daily gain, average feed consumption of concentrates per average daily gain, average feed consumption of concentrates per mean metabolic weight, and price per kilogram of live weight. This price is based on muscle conformation and is therefore used as muscle conformation score. Restricted maximum likelihood with a derivative-free algorithm was used to estimate (co)variance components because there were different models and missing values per trait. Estimates of heritabilities were above .50 except for average feed consumption per average
\end{abstract}

daily gain (.16) and average feed consumption per mean metabolic weight (.33). Estimates of genetic and phenotypic correlations between height at withers and weight traits were positive and moderate to high. Average daily gain showed a negative genetic correlation with weight at $7 \mathrm{mo}(-.68)$ but had positive correlations with height at withers at $13 \mathrm{mo}$ and weight at $13 \mathrm{mo}(.22$ and .43). Muscle conformation expressed as price per kilogram of live weight was related to low average feed consumption per average daily gain. Average feed consumption showed high correlations with weight at $7 \mathrm{mo}$ and weight at $13 \mathrm{mo}$. Average feed consumption per average daily gain had a high negative genetic correlation with average daily gain $(-.89)$.

Key Words: Heritability, Genotypes, Phenotypes, Correlated Traits, Performance Testing, Belgian Blue

J. Anim. Sci. 1995. 73:3269-3273

\section{Introduction}

In recent years cattle breeds in E urope have become more and more specialized. One classic example is the Holstein breed for milk production. Beef cattle breeds also have followed this pattern. The most extreme case is the Belgian Blue Breed (BBB). Selection in this breed is done with a two-stage selection scheme. The second stage is based on progeny-testing of Al bulls. The first stage is done at the Centre de Sélection de la Race BBB (CSB), where young bulls are performance-tested. Until now this selection was based on phenotype. Establishing a regular genetic evaluation based on a multiple-trait animal model would improve this selection. Even for those animals without infor-

\footnotetext{
${ }^{1} \mathrm{~N}$. Gengler is Aspirant of the Fonds National Belge de la Recherche Scientifique. To whom correspondence should be sent.

Received November 18, 1994.

Accepted August 2, 1995.
}

mation for feed consumption, breeding values would be available. Hanset and Michaux (1983) and Hanset et al. (1987) have previously studied this population for some of these traits. They used a sire model and Henderson's method III to estimate genetic parameters (Henderson, 1953). The main objective of this study is to perform a REML analysis (Patterson and Thompson, 1971) to obtain the (co)variance components needed for genetic evaluation with a multiple-trait animal model.

\section{Materials and Methods}

The Belgian Blue Breed

Beginning in the 1950s selection was conducted for muscular hypertrophy in the BBB breed. Such selection has been reported only in one other cattle breed, the Italian Piemontaise Breed (Renand, 1993). The Belgian meat market has paid and still pays premium 
prices for this type of animal, because the meat is very lean (Renand, 1993) and the carcasses have a high dressing percentage (Hanset et al., 1987). There is still a debate about the genetic determinism of the double-muscled condition. According to Georges et al. (1990) it is due to a major, partially recessive, gene, the "mh" gene, which stands for muscular hypertrophy. The intense selection for the double-muscled condition in the BBB breed is the basis of the physical appearance of these animals. But because other, additive, genes modify the expression of the " $\mathrm{mh}$ " gene, further selection for conformation is necessary even if the modern BBB breed is considered homozygous for the "mh" gene (Georges et al., 1990).

\section{Materials}

Animal Management. Data came from the CSB, which collects records for performance-tested bulls at three geographical locations. Young bulls are brought to the different locations at different ages. At one location the bulls enter for health reasons at the age of $2 \mathrm{wk}$ and at the other locations they enter no later than by the age of 6 mo. The animals normally are not raised as suckling calves. If they do suckle, it is only for a very short period of time.

Before the start of the test at $7 \mathrm{mo}$ of age, the animals go through a period of acclimation. The test is performed from 7 to 13 mo of age. Three different feeding periods are defined: up to 6 mo of age, from 6 to $10 \mathrm{mo}$, and after $10 \mathrm{mo}$. Animals are fed concentrates and straw. The first diet is based on barley flakes $(30 \%)$, oat flakes (20\%), linseed meal (20\%), and other minor ingredients. The second contains 35\% sugar beet pulp, $25 \%$ barley, $5 \%$ dehydrated alfalfa pellets, and $35 \%$ of a commercial concentrate called C2 that contains $45 \%$ linseed meal, $10 \%$ copra meal, $10 \%$ soy meal, $10 \%$ dehydrated alfalfa, $10 \%$ molasses, and other minor ingredients. The third diet is similar to the second with $35 \%$ sugar beet pulp, $20 \%$ barley, $30 \%$ of $\mathrm{C} 2$, and $15 \%$ dehydrated alfalfa pellets. All the animals are tested between 7 and 13 mo of age for growing performance. The facilities allow recording of feed consumption of concentrates for some, but not all, animals. At the age of $13 \mathrm{mo}$ the animals are evaluated for conformation using the value in Belgian francs per kilogram of live weight if they would have been sold for slaughter. Two different evaluations of price are done, one by a professional cattle dealer and one by a commission of farmers. These prices are a muscular conformation score; the values depend exclusively on muscular development. The commission of farmers also determine those animals that will be sold at a public auction that takes place several times during the year. This decision is based on phenotype. Belgian and foreign Al units as well as private breeders use this auction to obtain young sires.

Information was available for 1,442 bulls tested from 1986 to 1993 . This represents about 200 bulls per year. The capacity of the Centre has been expanded in recent years; test capacity was liberated from progenytesting done at the same time in the CSB before 1990. Therefore, fewer than 200 records per year were available before 1990 and more than 200 per year after 1990.

Traits. Nine traits were considered in this study: height at withers at $7 \mathrm{mo}$ (H7M), height at withers at $13 \mathrm{mo}$ ( H13M), weight at $7 \mathrm{mo}$ ( W7M), weight at 13 mo ( W13M), average feed consumption of concentrates (FC), average daily gain (ADG), average feed consumption of concentrates per unit of average daily gain (FCA), average feed consumption of concentrates per unit of mean metabolic weight (FCM), and price per kilogram of live weight (PKG). The definition of feed efficiency traits is such that "better" values are smaller values. The definition of FCA is used at the CSB and therefore was not changed. The trait PKG is the arithmetic mean of the dealer and commission prices per kilogram of live weight.

Pedigree I nformation. Two generations of ancestors were extracted from the pedigree database for each animal. Often sires and grandsires of animals had also been at this station, so additional ancestor generations were known in these cases.

\section{(Co)variance Components Estimation}

(Co)variance components were estimated using multiple-trait derivative-free restricted maximum likelihood ( MTDFREML) (Boldman and Van Vleck, 1991; Boldman et al., 1993). This method maximizes the log of the likelihood (e.g., Harville, 1977) using the derivative free approach first introduced by Graser et al. (1987) and popularized by Meyer (1988). The programs are based on the use of a sparse matrix solver (Boldman and Van Vleck, 1991). The simplex method (Nelder and Mead, 1965) is used to search for the parameter estimates that maximize the log of the likelihood function given the data. The main features of this set of programs are the flexibility to use different models for each trait and to allow for missing values. This flexibility was necessary because not all animals had all nine traits measured and because different traits were analyzed with different models.

Fixed contemporary groups at the start of the test were created on a fixed 45-d base and on the location of the animal. Some small groups were merged with adjacent groups. Different groups were created for weight traits (W7M, W13M), height at withers traits $(\mathrm{H} 7 \mathrm{M}, \mathrm{H} 13 \mathrm{M}), A D G$, and consumption traits (FC, FCA, FCM). Contemporary groups for PKG were based on date of evaluation for price per kilogram of live weight. This permitted correction for market price fluctuations. Actual age at weight near 7 mo (A7W), actual age at weight near 13 mo (A13W), length of test for daily gain ( LADG), actual age at beginning of feed consumption test (AFT), and actual length of feed consumption test ( LFT) were used as covariates. 
Table 1. Fixed effects and covariates in the different models used for analyzing the nine growth, feed consumption, and conformation traits

\begin{tabular}{lll}
\hline \hline Trait $^{a}$ & Fixed effect & Covariates \\
\hline H7M & Weight and height contemporary group & A7W; A7W $\times$ A7W \\
H13M & Weight and height contemporary group & A13W; A13W $\times$ A13W \\
W7M & Weight and height contemporary group & A7W; A7W $\times$ A7W \\
W13M & Weight and height contemporary group & A13W; A13W $\times$ A13W \\
ADG & Weight and height contemporary group & A7W; A7W $\times$ A7W; LADG; LADG $\times$ LADG \\
PKG & Price contemporary group & AFT; AFT $\times$ AFT; LFT; LFT $\times$ LFT \\
FC & Consumption contemporary group & AFT; AFT $\times$ AFT; LFT; LFT $\times$ LFT \\
FCA & Consumption contemporary group & AFT; AFT $\times$ AFT; LFT; LFT $\times$ LFT \\
FCM & Consumption contemporary group & \\
\hline
\end{tabular}

aDefinition of traits: $\mathrm{H} 7 \mathrm{M}$, height at withers at $7 \mathrm{mo}$; H13M, height at withers at $13 \mathrm{mo}$; W7M, weight at $7 \mathrm{mo}$; W13M, weight at $13 \mathrm{mo}$; ADG, average daily gain; PKG, price per kilogram of live weight; FC, average feed consumption of concentrates; FCA, average feed consumption of concentrates per average daily gain; FCM, average feed consumption of concentrates per mean metabolic weight.

${ }^{b}$ Definition of covariates: A7W, actual age at weight near 7 mo; A13W, actual age at weight near 13 mo; LADG, length of test for daily gain; AFT, age at beginning of feed consumption test; LFT, length of feed consumption test.

Summarized in Table 1 are the fixed effects and the covariates used for each trait. The model for each trait also contained an additive genetic effect of the animal and a random residual environmental effect.

Estimates were made for two, three, or four traits per analysis. Grouping of traits was done across the nine traits to get estimates for all covariances. Convergence was assumed when the variance of the likelihoods in the simplex was less than $10^{-9}$. Several restarts were done to avoid local maxima. The reported correlations and variances were obtained as the averages of final results for the analyses of different combinations done.

\section{Results and Discussion}

\section{Descriptive Statistics}

Shown in Table 2 are the mean values, observed coefficients of variation, and extreme measurements for the nine traits. The observed variation, especially for height and weight traits, was consistent with the common observation of BBB breeders that there is large phenotypic variation for these traits. The means and coefficients of variations were similar to those reported by Hanset and Michaux (1983) and Hanset et al. (1987).

\section{Heritabilities}

Estimates of heritability are presented in Table 3. The heritabilities were all higher than .50 except for the consumption traits of FCA with .16 and FCM with .33. Heritability for FCM may be higher because it measures average feed consumption relative to net energy required per day for maintenance, which is proportional to (weight). ${ }^{75}$ (Lofgreen and Garrett, 1968). The moderate estimate for FCM, and especially the low estimate for FCA, indicates that they might have little value as selection criteria if the goal is to improve feed efficiency. If the goal is to improve overall economic return it would be interesting to include FC, W13M, and PKG in an overall index.

Table 2. Number of observations, means, coefficients of variations, and minimum and maximum measurements

\begin{tabular}{|c|c|c|c|c|c|c|}
\hline Trait $^{a}$ & Unit & $\mathrm{n}$ & Minimum & Maximum & Mean & $\mathrm{CV}$ \\
\hline H7M & $\mathrm{cm}$ & 1,442 & 85 & 119 & 105.6 & $3.7 \%$ \\
\hline H13M & $\mathrm{cm}$ & 1,442 & 113 & 133 & 122.4 & $2.6 \%$ \\
\hline W7M & $\mathrm{kg}$ & 1,442 & 180 & 441 & 290.1 & $12.4 \%$ \\
\hline W13M & $\mathrm{kg}$ & 1,442 & 358 & 715 & 551.9 & $9.1 \%$ \\
\hline ADG & $\mathrm{kg} / \mathrm{d}$ & 1,442 & .463 & 2.086 & 1.472 & $12.9 \%$ \\
\hline PKG & $\mathrm{fb}^{\mathrm{b}} / \mathrm{kg}$ & 1,442 & 65 & 146 & 122.7 & $10.8 \%$ \\
\hline $\mathrm{FC}$ & $\mathrm{kg} / \mathrm{d}$ & 689 & 5.24 & 11.45 & 8.713 & $10.2 \%$ \\
\hline FCA & $\mathrm{kg} / \mathrm{kg}$ & 674 & 4.111 & 8.846 & 5.880 & $11.6 \%$ \\
\hline $\mathrm{FCM}$ & $\mathrm{kg} /\left(\mathrm{d} \cdot \mathrm{kg} \cdot{ }^{75}\right)$ & 674 & .056 & $\begin{array}{r}.042 \\
.122\end{array}$ & .094 & $\begin{array}{r}7.7 \% \\
\end{array}$ \\
\hline
\end{tabular}

${ }^{a}$ Definition of traits: $\mathrm{H} 7 \mathrm{M}$, height at withers at $7 \mathrm{mo}$; H13M, height at withers at $13 \mathrm{mo}$; W7M, weight at $7 \mathrm{mo}$; W13M, weight at 13 mo; ADG, average daily gain; PKG, price per kilogram of live weight; FC, average feed consumption of concentrates; FCA, average feed consumption of concentrates per average daily gain; FCM, average feed consumption of concentrates per mean metabolic weight.

bfb, Belgian francs ( $\pm \$ .03)$. 
Table 3. Estimates of genetic (below diagonal) and phenotypic correlations (above diagonal) and heritabilities (diagonal) for the nine traits

\begin{tabular}{|c|c|c|c|c|c|c|c|c|c|}
\hline Trait $^{a}$ & $\mathrm{H} 7 \mathrm{M}$ & H13M & W7M & W13M & ADG & PKG & $\mathrm{FC}$ & FCA & FCM \\
\hline H13M & .89 & .80 & .50 & .60 & .40 & -.01 & .45 & -.05 & -.03 \\
\hline W13M & .90 & .54 & .50 & .51 & .70 & .26 & .70 & -.24 & .01 \\
\hline ADG & .00 & .22 & -.68 & .43 & .55 & .18 & .45 & -.66 & .24 \\
\hline PKG & .00 & .15 & .14 & .37 & .16 & .80 & .42 & .09 & .01 \\
\hline FCM & .31 & -.06 & .53 & -.46 & -.70 & -.03 & .01 & .00 & .33 \\
\hline$P V^{b}$ & 21.7 & 11.8 & 1,385 & 2,594 & .0355 & 68.1 & .603 & .353 & .0000300 \\
\hline
\end{tabular}

aDefinition of traits: $\mathrm{H} 7 \mathrm{M}$, height at withers at $7 \mathrm{mo}$; $13 \mathrm{M}$, height at withers at $13 \mathrm{mo}$; W7M, weight at $7 \mathrm{mo}$; $13 \mathrm{M}$, weight at 13 mo; ADG, average daily gain; PKG, price per kilogram of live weight; FC, average feed consumption of concentrates; FCA, average feed consumption of concentrates per average daily gain; FCM, average feed consumption of concentrates per mean metabolic weight.

bPV, phenotypic variance.

The muscular conformation measurement (PKG) showed a high heritability even though a major gene seems to play an important role in its expression. An explanation for the high heritability of PKG could be a bias during evaluation in favor of animals from lines that are thought to be superior. Indications from the field concerning pricing practice of live animals for price per kilogram of live weight support this hypothesis ( $F$. Boonen, personal communication). The variance that is supposed to be genetic could contain in reality a nongenetic, sire $\times$ environment component. Additional studies should be done that include a random sire $\times$ contemporary group effect in the model, as used in U.S. dairy cattle evaluation. The professional cattle dealer and the members of the commission also should not know the pedigrees of the animals before the evaluation so that any potential for this bias could be avoided.

The heritabilities found in this study are very different from those reported by Hanset and Michaux (1983), who found very low estimates for all traits of between .06 and .15 for height (H7M, H 13M) and weight traits (W7M, W13M), ADG, and PKG. Hanset et al. (1987) also reported lower estimates of .27 for W7M, .20 for W13M, .44 for ADG, and .28 for FC; however, their estimate of .39 for FCA exceeded that in Table 3. Both studies used a sire model and Henderson's Method III for variance component estimation with smaller datasets based on older data from the CSB. These results can be compared with those from continental European-type beef breeds and English beef breeds as well as dual-purpose and dairy breeds. Miglior et al. (1994) reported heritabilities for Limousin station-tested bulls and found .56 for weight at end of test, .43 for height at hooks at end of test, . 55 for ADG during test (140 d), and .51 for muscular development score. The current results presented in Table 3 are similar but are higher for height and muscular development (price) traits. Bishop (1992) reported, for performance-tested Hereford bulls, lower heritabilities for weight at $200 \mathrm{~d}$ and weight at $400 \mathrm{~d}$ (.26 and .43, respectively) than shown in Table 3. He found estimates of .30 for feed consumption and .14 for the feed conversion ratio, which are similar to those in Table 3 for FCA, but lower than for FC. The estimate of Bishop (1992) for feed consumption per mean metabolic weight (.12) are lower than the estimates in Table 3 for FCM. J ensen and Andersen (1984) reported heritability estimates for performance-tested dairy breed bulls for weight traits ranging between .19 and .54 , with the higher heritabilities for measures taken on older animals. Their results are similar to those in Table 3 for W7M and W13M, but Table 3 does not show this increase in heritability. Estimates of heritability for daily gain ranged from .27 to .53 in J ensen and Andersen (1984), in contrast to those in Table 3 for ADG. In contradiction to the results reported in this study for FCA and to the result given by Bishop (1992), Jensen and Andersen (1984) reported a moderate estimate of heritability for feed consumption over gain (.45).

\section{Correlations}

Genetic and phenotypic correlations are also presented in Table 3. The height and weight traits were strongly correlated, as might be expected, with genetic correlation of .98 between H7M and W7M. Phenotypic correlations were lower but still all over .50. Hanset and Michaux (1983), however, found negative genetic correlations between height and weight traits. A more recent study on the Limousin breed by Miglior et al. (1994) also reported a high genetic relationship (.56) between height and weight traits.

Average daily gain had a strong negative genetic correlation with W7M of -.68. This result may indicate that differences in precocity exist among animals within the BBB breed. Hanset and Michaux (1983) reported an estimate of -.62 for the same correlation 
between ADG and W7M, whereas Hanset et al. (1987) reported an estimate of -.34 . J ensen and Andersen (1984) and Bishop (1992) reported positive correlations, but for other breeds. Height at 13 mo (H 13M) and W13M showed moderate genetic correlations with ADG (.22 and .43) but moderate to high phenotypic correlations (.40 and .70). Hanset et al. (1987) found .65 and .53 as genetic and phenotypic correlations between ADG and W13M. Miglior et al. (1994) reported the same pattern for weight, but not for height. This seems to indicate that for the BBB breed taller animals have better ADG, a result that is not necessarily found for less extreme beef breeds.

The price per kilogram of live weight was only moderately correlated to other traits except for FCA $(-.88)$. The negative genetic correlation observed between PKG and FCA seems to support the common thesis that more extremely double-muscled animals need less feed to achieve the same gains as those showing less muscling.

Average feed consumption had high correlations with W7M and $\mathrm{W} 13 \mathrm{H}$; phenotypic correlations ranged to .70 with W13M. The corresponding genetic correlations were extremely high, .99. Bishop (1992) reported similar results, but these results are not the same as those found by J ensen and Andersen (1984). The results for FCA showed high positive genetic correlation with W13M (.88), a result that disagreed with results of Bishop (1992) and J ensen and Andersen (1984). This could be a result that is specific for the BBB breed. Also, a high negative genetic correlation was found for FCA with ADG $(-.89)$. This estimate is close to those reported by J ensen and Andersen (1984) for correlations between gains and feed conversion ratios. Correlations between FCM and the other traits were low to moderate except for the genetic correlations of FCM with W7M (.53) and with ADG $(-.70)$ and the phenotypic correlation of FCM with FC (.52). Bishop (1992) also found moderate positive genetic correlations of feed consumption per mean metabolic weight with gain and weight, but high phenotypic correlations (.70) between feed consumption per mean metabolic weight and feed consumption.

\section{Implications}

Little information on genetic parameters needed for genetic evaluations of Belgian Blue performancetested bulls is available. This research provides estimates of genetic parameters needed to do multiple- trait animal model genetic evaluations for the Belgian Blue bulls that are performance-tested. These genetic evaluations should improve the accuracy of selection in this breed and increase overall genetic gain, especially for traits that are difficult to observe in the field such as feed consumption.

\section{Literature Cited}

Bishop, S. C. 1992. Phenotypic and genetic variation in body weight, food intake and energy utilisation in Hereford cattle. I. Performance test results. Livest. Prod. Sci. 30:1.

Boldman, K. G., L. A. Kriese, L. D. Van Vleck, and S. D. Kachman. 1993. A manual for the use of MTDFREML. A set of programs to obtain estimates of variances and covariances. USDA, Clay Center, NE.

Boldman, K. G., and L. D. Van Vleck. 1991. Derivative-free restricted maximum likelihood estimation in animal models with a sparse matrix solver. J. Dairy Sci. 74:4337.

Georges, M., M. Lathrop, P. Hilbert, A. Marcotte, A. Schwers, S. Swillens, J. Roupain, Y. Bouquet, G. Vassart, and R. Hanset. 1990. Etude du gène "mh" (muscular hypertrophy) bovin par génétique inverse. Nouvelles de la Science et des Technologies 8:47.

Graser, H.-U., S. P. Smith, and B. Tier. 1987. A derivative-free approach for estimating variance components in animal models by restricted maximum likelihood. J. Anim. Sci. 64:1362.

Hanset, R., and C. Michaux. 1983. Le performance-test et le progeny-test viande en station, analyse statistique et géné tique. In: Dix Années - Centre de Sélection Bovine Ciney 1973-1982, Ministry of Agriculture, Belgium.

Hanset, R., C. Michaux, and A. Stasse. 1987. Relationships between growth rate, carcasse composition, feed intake, feed conversion ratio and income in four biological types of cattle. Genet. Sel. Evol. 19:225.

Harville, D. A. 1977. Maximum likelihood approaches to variance component estimation and to related problems. J. Am. Stat. Assoc. 72:320.

Henderson, C. R. 1953. Estimation of variance and covariance components. Biometrics 9:226.

J ensen, J ., and B. B. Andersen. 1984. Performance testing of future A.I. bulls for growth rate, feed efficiency and muscularity. Genetic parameters, adjustment for systematic environmental factors, selection indices. Livest. Prod. Sci. 11:475.

Lofgreen, G. P., and W. N. Garrett. 1968. A system for expressing net energy requirements and feed values for growing and finishing beef cattle. J. Anim. Sci. 27:793.

Meyer, K. 1988. Programs to estimate variance components for individual animal models by restricted maximum likelihood. User Notes. Univ. of Edinburgh, U.K.

Miglior, F., R. A. Kemp, and E. B. Burnside. 1994. Genetic parameter estimates of conformation and performance traits in station-tested Limousin bulls. Can. J. Anim. Sci. 74:379.

Nelder, J. A., and R. Mead. 1965. A simplex method for function minimization. Comput. J . 7:147.

Patterson, H. D., and R. Thompson. 1971. Recovery of inter-block information when block sizes are unequal. Biometrika 58:545.

Renand, G. 1993. Perspectives d'amélioration génétique de la qualité de la viande. Study-day: La qualité de la viande bovine: réalité ou mythe? Faculté des Sciences Agronomiques, Gembloux, Belgium. 